\title{
太陽光発電に関する最近の状況と展望
}

\author{
正 員 黒川 浩助*
}

\section{The State-of-the Art of Solar Photovoltaics and its Future Direction}

Kosuke Kurokawa*, Member

The successful history of solar photovoltaic technology in Japan is reviewed quickly and then present photovoltaic implementations in Japan, US and Europe are summarized in short. Japan set up "PV2030 roadmap" in 2004, targeting 25\% PV cell efficiency and $100 \mathrm{GW}$ installation over Japan. "Cool Earth PV2050"has been being discussed to make innovative technologies clearly contribute to the post-Kyoto mechanism. Finally, the author is directing future solar photovoltaic technology capabilities towards one of possible major energy approach for $21^{\text {st }}$ century.

キーワード：再生可能エネルギー, 太陽光発電技術, PV2030, cool earth

Keywords: renewable energy, photovoltaic system, PV2030, cool earth

\section{1. はじめに}

第 1 次石油危機の直後の 1974 年に当時のサンシャイン 計画が発足した。このときの 4 大分野のひとつとして太陽 電池技術を含む太陽エネルギー開発計画の, 2000 年までの 基本計画が設定された。1980 年 10 月の新エネルギー総合 技術開発機構（NEDO：現・新エネルギー・産業技術総合 開発機構）の創立とともに，太陽光発電の技術開発は年間 70～80 億円程度の安定した国家プロジェクトとして着実な 技術発展を遂げた ${ }^{(1)}$ 。

1990 年代前半には系統連系が可能になり, 余剰電力購入 メニューが適用される中，1994 年に住宅用システムに対 する設置補助金制度が創設された。以後，国内の太陽光発 電市場は急速に拡大し, 太陽電池モジュール出荷量は世界 トップシェアを誇るようになった ${ }^{(1)}$ 。

しかし，2005 年度の住宅用補助金制度の終了, シリコン 原料供給逼迫などが契機となり，今までの好調にかげりが 生じている。このような厳しい状況にありながらも，より 長期的な視点から新しいフェーズへと展開しつつある。以 下ではこのような背景のもとに実施されている技術開発枠 組みや, 超長期な視点で今後望まれる技術の方向性などに ついて解説を試みる。

\section{2. 日米欧の現状俯瞰}

表 1 により，現状の日米欧の技術開発戦略，国内普及策 および市場の概要を示した (2)。日本は，2004 年に設定した $\lceil P V 2030$ ロードマップ(3)(4)」に記載された長期目標に向かっ

\footnotetext{
* 東京工業大学 統合研究院ソリューション研究機構

干 152-8550 東京都目黒区大岡山 2-12-1

Tokyo Insitute of Technology

2-12-1, Ookayama, Meguro-ku, Tokyo 152-8550
}

て, NEDOにより技術開発が進められている。2030年には， モジュール効率 $22 \% に よ り 50$ 円/W を目標とし, 7 円/kWh が可能としている。また 2006 年 5 月には「新・国家エネ ルギー戦略 ${ }^{(5)}$ に火力発電なみの発電コスト目標が記述さ れている。

米国では 2006 年にソーラー・アメリカ・イニシアチブ $(\mathrm{SAI})^{(6)}$ により長年の沈黙を破って積極的な目標を掲げた。 また, 10 余州でも強力な施策が採用され, カルフォルニア 州では顕著な導入実績を上げている。

欧州では，ドイツを始め各国のフィードインタリフ (FIT) (7) 制度導入により大幅に市場活性化されている。電気事業の 太陽光発電電力の買い取り価格を, 建設時点でたとえば 20 年間にわたり通常の電気価格の 2〜3 倍を保証する制度で, 早期導入を促す仕組みとなっている。

わが国では 2005 年度以降, 前述した諸事情により, 国内 導入が一時的に停滞し, 活発なドイッの国内導入量に抜き 去られた。総年出荷量でも，ドイッや中国企業などに追い 上げられている。まさに正念場といえる状況になっている。

\section{PV2030 ロードマップおよびその他の見通し}

「PV2030 ロードマップ」による目標設定では, 図 1 に示 されるように，より大量生産に適しコスト低減を実現できる ような太陽電池技術へ交代していくシナリオを想定してい る。その前提条件として, 2030 年には日本の電気の $10 \%$ 供 給にあたる $100 \mathrm{GW}$ 導入をべースケースとして想定してい る。また例えば, 個人住宅用太陽光発電でオール電化が可 能な，7〜8kW/戸を実現するためのモジュール変換効率を

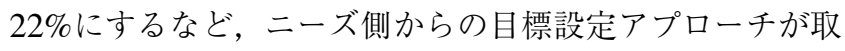
られたのが特徴である(4)。

表 2 は, 資源エネルギー庁による 2005 年の旧エネルギー 
表 1 太陽光発電にかかわる日米欧の現状比較 ${ }^{(2)}$

Table 1. Comparison of present status in photovoltaic implementations among Japan, US and Europe.

\section{日本}

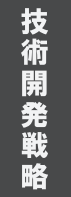

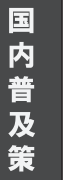

市

場 2005年で終了
PV2030ロードマップによる

太陽光発電技術開発

-2010年 $23 ¥ / k W h$

- 2020 年 $14 ¥ / k W h$

-2030年 $\quad 7 ¥ / K W h$

·住宅用太陽光発電支援は、

·公共産業用FT事業

·余剰電力購入メニュー

(電力会社の自主メニュー)

.2006年需要 $287 \mathrm{MW}$

·住宅用途が, $85 \%$

·年間伸率-3\%, 2007低迷

(国内市場閉塞·輸出7割以上)

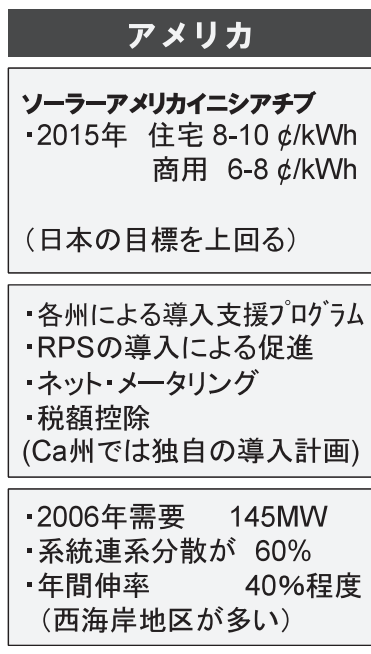

シーロッパ

EU太陽光発電技術開帚

プラットフォーム (WG3)

-2015年 $2.5 € / \mathrm{kW}$

$0.15 € / \mathrm{kWh}$

（現実的な目標を設定）

\begin{tabular}{|c|}
\hline -FIT方式(20年間固定買取) \\
2007 年 (ドイツの例) \\
$30 \mathrm{KW}>48.21 \phi / \mathrm{kWh}$ \\
$30-100 \mathrm{~kW} \quad 46.32 \phi / \mathrm{kWh}$ \\
$100 \mathrm{~kW}<46.30 \phi / \mathrm{kWh}$ \\
\hline -2006年需要 $953 \mathrm{MW}$ (ドイツ) \\
$61 \mathrm{MW}$ (スペイン) \\
-住宅40\%/大型 $50 \% /$ 発電10\% \\
-EU年間伸率 $12.7 \%$ \\
\hline
\end{tabular}

$\sqrt{\text { ・台湾·インドによる, フルターンキー新規生産投資 }}$ 日本の国際競争力? 新しい動问 · ·国生産量の異常な拡大・ドイッの中国投資 - 海外半導体産業からの太陽光発電への新規参入

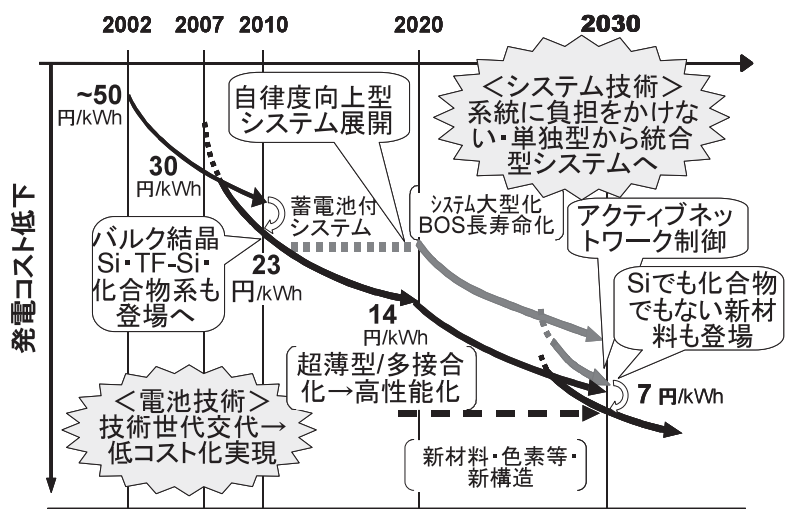

図 1 PV2030 ロードマップ・シナリオ ${ }^{(3)(4)}$

Fig. 1. R\&D scenario by NEDO's "PV2030 Roadmap".

需給見通しと 2008 年 3 月の新見通しにおける新エネルギー の導入推計の比較である ${ }^{(8)(9)}$ 。後者における地球温暖化対 策のための「最大導入ケース」では, 2005 年度の電力供給 比率 $21 \%$ の原子力を 2020 年度 $44 \%, 2030$ 年度 $49 \%$ に増 強することを主体として，2020 年までに約 52 兆円の社会 的負担が必要としている(10)。

この場合のエネルギー起源 $\mathrm{CO}_{2}$ 排出量は, 1990 年比で, 2010 年 $+1.3 \%, 2020$ 年度 $-3 \%, 2030$ 年度 $-13 \%$ としてお り，一方で打ち出されている洞爺湖サミットの議長国方針 との違和感が議論も呼んでいる ${ }^{(11)}$ 。新エネルギー導入につ いても過去の見通しに比べ後退していることは否めない。 新エネルギー全体の伸び率は 3 倍 (2005 年度対 2030 年度) と見ており，この中で太陽光発電について伸び率 37 倍と高 い成長可能性を認めている。2005 年度現在で戸建て約 32 万戸に太陽光発電は導入されているが, 2020 年度には, 新 築持家住宅の約 7 割に導入し, 約 320 万戸と現状の約 10 倍に達するとしている。
表 2 エネルギー需給見通しにおける新エネルギー供給

Table 2. New energy outlook by METI.

(単位：原油換算 $\mathrm{k} \ell$ )

\begin{tabular}{|r|c|c|c|}
\hline \multicolumn{1}{|c|}{ 年 } & 2010 & 2020 & 2030 \\
\hline 2005.3 見通し·総計* & 1910 万 $\mathrm{k} \ell$ & & 3947 万 $\mathrm{k} \ell$ \\
\hline 万ち太陽光発電分 & 118 万 $\mathrm{k} \ell$ & & 2024 万 $\mathrm{k} \ell$ \\
太陽光発電容量 & $4.82 \mathrm{GW}$ & & $(83 \mathrm{GW})$ \\
\hline 2008.3 見通し·総計** & 1910 万 $\mathrm{k} \ell$ & 2036 万 $\mathrm{k} \ell$ & 3202 万 $\mathrm{k} \ell$ \\
万ち太陽光発電分 & 118 万 $\mathrm{k} \ell$ & 350 万 $\mathrm{k} \ell$ & 1300 万 $\mathrm{k} \ell$ \\
太陽光発電容量 & $(4.82 \mathrm{GW})$ & $(14.3 \mathrm{GW})$ & $(53 \mathrm{GW})$ \\
\hline
\end{tabular}

注*) 総合資源エネ調査会需給部会：「2030 年のエネルギー需給展望」, 新 エネ進展ケース, p.108 (2005-3)

注**) 総合資源エネ調査会需給部会：2010 年度分：p.63, 「追加対策シナリ オ上位ケース」; 2030 年度分 : p.31, 「最大導入ケース」, 長期エネル ギー需給見通し (2008-3)

\section{4. 超長期世界太陽光発電市場展望}

図 2 は超長期の市場規模推移シナリオの想定例であ る ${ }^{(12)(13)}$ 。その前提は世界エネルギー供給にどれ程寄与でき るかに置かれている。ここで, 西暦 2100 年までの世界一次 エネルギー供給量（TPES）として，ドイツの環境諮問会議 WBGU シナリオと, 気候変動に関する政府間パネル IPCC の $\mathrm{A} 1 \mathrm{~T}$ シナリオを参照した。前者は，地球環境問題解決を ベースにしたシナリオ ${ }^{(14)}$ で, 2100 年の TPES は $1600 \mathrm{EJ} / \mathrm{Y}$ $\left(\mathrm{EJ}=10^{18} \mathrm{~J}\right)$ に達すると予測, 太陽電気が TPES の 2/3を 供給するとした。後者では 2100 年に $2000 \mathrm{EJ} / \mathrm{Y}$ を想定, バ イオマスを含む再生可能エネルギーが全供給の 4/5 になっ ている ${ }^{(15)}$ 。

図 2 最上部では A1T シナリオの世界全量を太陽光発電で まかなったと仮定した太陽光発電換算単位 (TW) で表示し た (等価稼働時間を 1000 時間/年とし，1 TW は $1000 \mathrm{TWh}$ に相当)。太陽光発電導入量は最終的に, 太陽熱発電も同量 
と見て, WBGU 太陽電気の $1 / 2$ の $133 \mathrm{TW}$ となる。この值 に対して現状導入量から飽和曲線を描くと上部 2 番目の曲 線となる。さらに，世紀後半のモジュール寿命を 30 年とし て割り算すると, 2100 年 $4.4 \mathrm{TW} / \mathrm{Y}$ が持続的な年生産量と なる。年市場規模カーブ（3 番目の曲線）を引くと，2030 年には $100 \mathrm{GW} /$ 年, 2050 年 $1 \mathrm{TW} /$ 年, 2100 年 $4.4 \mathrm{TW} /$ 年 と概観できる。

2100 年に生産された太陽電池全量が，耐用年数に達した 既設設備を更新， 2020 年頃では現状寿命 20 年のモジュー ルの更新需要が立ち上がる。2030 年頃には 30 年に延びる ので，更新カーブ（4 番目の曲線）を作成すれば，2040 年 $10 \mathrm{GW} /$ 年, 2060 年 $100 \mathrm{GW} /$ 年, 2080 年 $1 \mathrm{TW} /$ 年, 2100 年 $4.4 \mathrm{TW} /$ 年となる。これはリサイクル産業の規模を示して いる。

さらに市場規模カーブから，1 ライン当たりの規模を推測 した。現在は $100 \mathrm{MW} /$ 年/ライン規模と言われる。世界を 100 ラインで供給すると見れば, 2030 年には $1 \mathrm{GW} /$ 年/ライ ンが必要になり，2050 年 $10 \mathrm{GW} /$ /ラン，2100 年 $40 \mathrm{GW} /$ ラインが要求される。これは目指すべき製造速度の指標で ある。

例えば，生産能力 $1 \mathrm{GW} / \mathrm{Y}$ のラインに要求される製造速 度は, PV2030 の目標のモジュール効率 $22 \%$ として, $20 \mathrm{~cm}$ 角の超薄型セルの場合, 毎秒 4.4 枚の接合形成速度が必要で ある。仮に $1.8 \mathrm{~m}$ 角のモジュールを製造するとすれば，毎 分 3.3 パネルをアセンブルしなければならない(16)。

また，モジュール生産量の半分を住宅用に利用した場合 には, $5 \mathrm{~kW}$ インバー夕換算で, 月産 8350 台の生産ライン が必要となる。残り半分を $700 \mathrm{~W}$ インバータ付き AC モ ジュールとした場合には，月産 59000 個の産業が必要であ

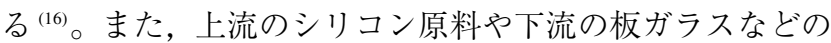
関連産業規模についても検討が加えられている。

\section{Cool Earth一革新型太陽光発電技術開発}

2008 年 7 月に洞爺湖において G8 サミットが開催される。 2007 年ドイツ G8 サミットでは安倍前首相が，2050 年に世

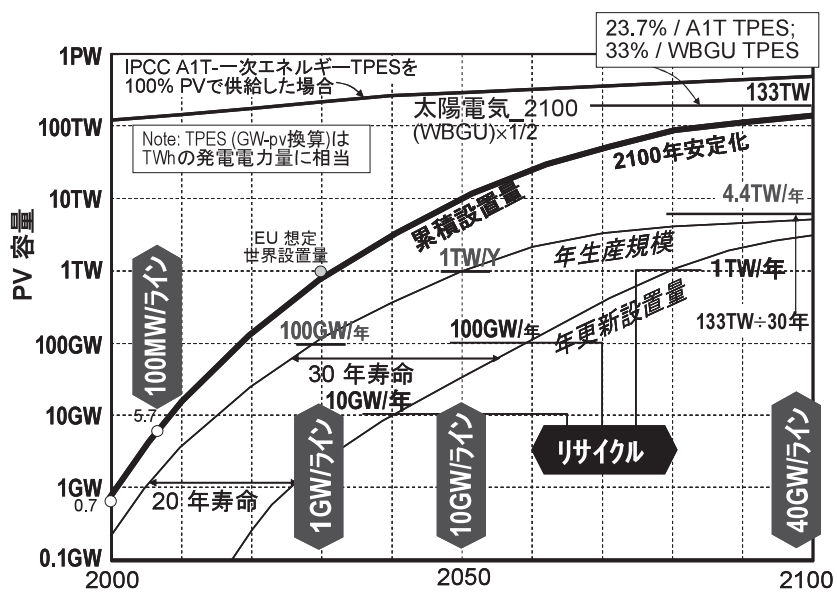

図 2 超長期の世界太陽光発電市場規模推定 ${ }^{(12)}$

Fig. 2. Ultra long term projection of photovoltaic world market.
界の $\mathrm{CO}_{2}$ 排出半減を訴えた。福田政権はクールアース 50 有識者会議を設定し，21 技術からなる「Cool Earth一エネ ルギー革新技術計画」を策定した ${ }^{(17)}$ 。太陽光発電は 4 番目 の技術として選定されている。この具体化のためにNEDO では「革新型太陽光発電技術開発計画」が検討され，2008 年 3 月時点で公募中である ${ }^{(18)}$ 。

同計画では図 3 の第 3 世代技術を，ブレークスルーを必 要とするが長期的な視点で可能性が期待できるものとして, 表 3 で例示している。一方，現状で商業化しているものを 第 1 世代技術, PV2030 ロードマップが目指すものを第 2 世 代技術として性格付けした。第 3 世代 (3G) という考え方 は，オーストラリアのグリーン教授が提唱 ${ }^{(19)}$ し，欧米 ${ }^{(20)(21)}$ でも基礎的な検討をすでに開始している。

\section{6. 超長期の太陽光発電技術の方向性}

以上のような背景を考慮し，筆者は図 4 のようにシステ 么分野をも含めた将来技術の方向性を提示した ${ }^{(22)}$ 。第 1 〜 第 3 世代技術およびリサイクル技術 ${ }^{(23)}$ を順次展開し，応用 技術面で，開発途上地域，都市型のコミュニティ，大規模 システム・地球規模系統への展開の 3 大分野を描いた。

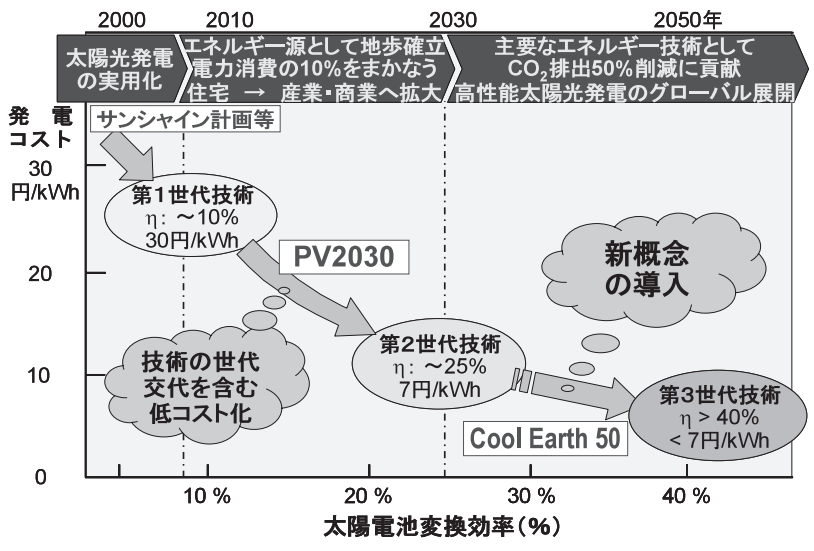

図 3 Cool Earth 50 に貢献する 2050 年に向けた 技術開発

Fig. 3. R\&D toward 2050 to contribute "Cool Earth 50 Program".

表 3 第 3 世代で実現すべき技術レベルの例示 ${ }^{(18)}$

Table 3. Desirable level examples of third generation technologies.

\begin{tabular}{|c|c|c|}
\hline 技術分野 & 取組みテーマ & $\begin{array}{l}\text { 到達の目安 } \\
\text { (7年後) }\end{array}$ \\
\hline \multirow{3}{*}{$\begin{array}{llll}\text { 多 } & \text { 接 } & \text { 合 } & \text { 型 } \\
\text { 太 } & \text { 陽 } & \text { 電 } & \text { 池 }\end{array}$} & $\begin{array}{l}\text { 高倍率集光対応多接合 } \\
\text { 太陽電池 }\end{array}$ & $\begin{array}{l}\text { 非集光 } \eta: 35 \% \\
\text { 集光 } \quad \eta: 45 \%\end{array}$ \\
\hline & 薄膜系大面積型多接合 & $\eta: 25 \%$ \\
\hline & 量子ドット型多接合 & $\eta: 15 \%$ \\
\hline $\begin{array}{l}\text { 量子ナノ構造 } \\
\text { 太 陽 電 池 }\end{array}$ & $\begin{array}{l}\text { 中間バンド構造, ホット } \\
\text { キャリア型, マルチエキ } \\
\text { シトン効果 }\end{array}$ & $\eta: 10 \%$ \\
\hline デバイス周辺 & 光調整技術高性能化 & 太陽電池適用 \\
\hline 光マネジメント & 波長変換技術の適用 & の可能性実証 \\
\hline $\begin{array}{l}\text { その他の新規 } \\
\text { 概 念セ ル }\end{array}$ & $\begin{array}{l}\text { TPV技術，プラズ 玵型, } \\
\text { 非半導体p n接合型等 }\end{array}$ & $\eta: 10 \%$ \\
\hline
\end{tabular}




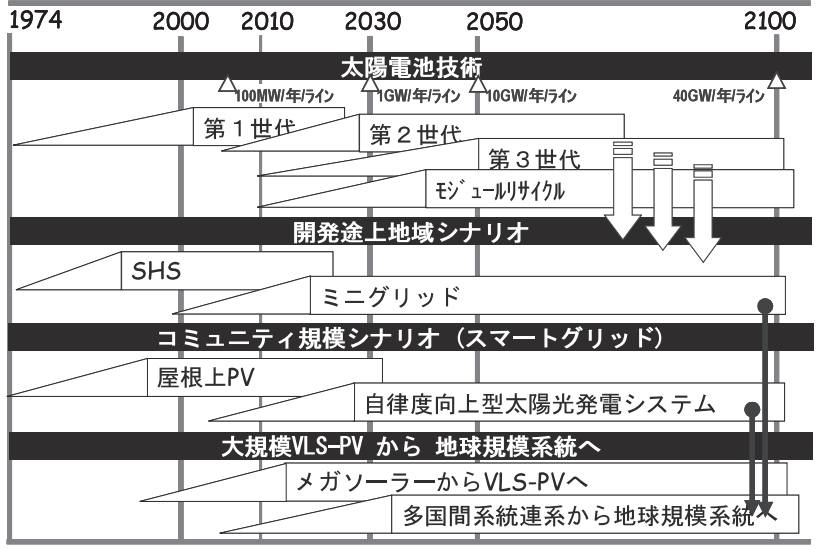

図 4 超長期の太陽光発電技術の方向性 ${ }^{(22)}$

Fig. 4. Ultra long term direction of photovoltaic technologies.

途上地域では, 数 $100 \mathrm{~W}$ 程度までの個別ソーラーホーム システム（SHS）から村落電化のためのミニグリッド，都 市型コミュニティのルーフトップシステム集合 ${ }^{(24)}$ からマイ クログリッド型系統概念 ${ }^{25)}$ へ展開するとした。住宅太陽光 発電と負荷が混在融合した自立度向上型地域システム ${ }^{(26)}$ の 提案もある。広域での電力供給アプローチとしては未利用

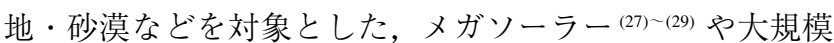
太陽光発電 (VLS-PV) ${ }^{(30)(31)}$ から, 多国間連系や地球規模の 広域運営インフラ系統 ${ }^{(31)(32)}$ への接続を例示している。

\section{7. まとめ}

超長期展望において, 太陽光発電は再生可能エネルギーの 最有力という見方は少なくはない。50 年の夕イムスパンで 見た持続可能システムが，100 年単位で持続可能か? 100 年持続するといえても，1000 年の持続性を保証できるか? このような命題では太陽エネルギーに支えられた生態系に 対して，人間社会が与える負荷の大きさを，前者のキャパ シティを超えない範囲に止めなければならない。それに対 し，生態系の制約を超えた屋根上や砂漠などに立地した太 陽光発電はこの限界を拡張できそうである(22)。技術による 持続的サイクルとは，このようなトータルシステムを実現 することではないかと思考しつつ，本稿を終えたい。

(平成 20 年 4 月 8 日受付)

\section{文献}

（1）NEDO BOOKS 編集委員会編：なぜ，日本が太陽光発電で世界一に なれたのか, NEDO (2007)

（2）黑川浩助:「基調講演 (最新の課題)」, 太陽光発電協会セミナー, RE2007, 幕張メッセ (2007-10)

（3） 2030 年に向けた太陽光発電ロードマップ（PV2030）検討委員会報 告書, NEDO (2004)

（4）「2030 年に向けた太陽光発電ロードマップ (PV2030)」, NEDO/PV2030 検討委員会:

http://www.nedo.go.jp/informations/other/161005_1/gaiyou_j.pdf

（5）資源エネルギー庁：新・国家エネルギー戦略 (2006-5) http://www.meti.go.jp/press/20060531004/20060531004.html

（6）例えば,「米国の太陽光エネルギー・イニシアティブの現状」, NEDO 海外レポート,No.995 (2007-2)
（7）例えば, 一木 修：「太陽光発電産業について」, 総合資源エネ調査 会第 15 回新工京部会, 資料 2, p.19(2006-3)

（8）総合資源エネ調查会需給部会：「2030 年のエネルギー需給展望」,新 エネ進展ケース (2005-3)

（9）総合資源エネ調査会需給部会：長期エネルギー需給見通し (2008-3)

（10）「2020 年の最大導入ケース害現の姿」経産省プレスリリース, http://www.meti.go.jp/committee/materials/downloadfiles/g80319b04j.pdf

(11) 「経産省の不可解な排出予測」, 日経社説 (2008-3.21)

(12) K. Kurokawa: "Future direction of PV system technologies around 2030 and beyond", PVSEC-17, Fukuoka, 3-7 Dec. 2007, PL7-1. PVSEC-17, Fukuoka (2007-12)

（13）黑川浩助：「寄稿：太陽光発電時代の節目」, 太陽光発電協会機関誌, pp.29-37 (2008-3)

(14) WBGU: German Advisory Council on Global Change: "World in Transition—Towards Sustainable Energy Systems", Summary p.3 (2003) http://www.wbgu.de/wbgu_jg2003_engl.html

(15) IEA: Energy to 2050 scenarios for a sustainable future, p.198 (2003)

16) K. Kurokawa: "Mass Production Scale of PV Modules and Components in 2030s and beyond", PVSEC15, PV0926-05i, Shanghai (2005-10)

(17) 経済産業省：Cool Earth-エネルギー革新技術計画の策定について (2008-3)

http://www.meti.go.jp/press/20080305001/20080305001.html

18） NEDO:「革新的太陽光発電技術研究開発（革新型太陽電池国際研究 拠点整備事業)」の公募について (2008-3)

https://app3.infoc.nedo.go.jp/informations/koubo/koubo/FF/ nedokouboplace.2008-03-13.7286783756/ nedokoubo.2008-03-17.2664727467/

(19) M. Green: Third generation photovoltaics, Springer (2003)

(20) http://www.fullspectrum-eu.org/downloads_external/Publishable_executive_ summary_year3.pdf

(21) http://www.pv-tech.org/___and_d/article/energy_focus_wins_1_million_ contract_for_high_efficiency_solar_cell_project/

(22) K. Kurokawa: "Future direction of PV system technologies around 2030 and beyond", PVSEC-17 Digest, PL7-1, Fukuoka (2007-7)

（23）例えば, 黑川浩助：「世界の太陽電池開発動向ならびに PV リサイ クルの動向とグリーン電力証書の課題」, 太陽光発電協会セミナー, pp.6-8, 幕張メッセ (2007-10) http://www.jpea.gr.jp/1/1_keynote_address.pdf

（24）例えば, S. Nishikawa and K. Kato: "Demonstrative research on grid-interconnection of clustered photovoltaic power generation systems", 3rd World Conference on Photovoltaic Energy Conversion, 8LN-C-03 (2003)

(25) 例えば, 「需要地系統における電圧適正化方式の開発一分散形電源 の無効電力を活用した新しい電圧上昇抑制法一」, 電中研 2007 研究 年報, pp.62-63 (2007) http://criepi.denken.or.jp/jp/pub/annual/2007/07bunya42.pdf

26) K. Kurokawa: "Further considerations on solar PV community concept consisting of massive roof-top PVs and domestic loads", EUPVSEC-22, Milan, 5BP.2.5 (2007-9)

(27) S. Miwa, et al.: "Introduction of Wakkanai Mega-Solar Project", PVSEC-17 Digest, 5O-C6-04, Fukuoka (2007-12)

28) H. Konishi, R. Tanaka, and T. Shiraki: "Introduction of Hokuto Mega-Solar Project", PVSEC-17 Digest, 5O-C6-04, Fukuoka (2007-12)

(29) "Large-scale photovoltaic power plants", http://www.pvresources.com/en/top50pv.php

(30) K. Kurokawa, Ed: Energy from the desert-Feasibility of very large scale photovoltaic power generation (VLS-PV) systems, James\& James (2003-5)

(31) K. Kurokawa, K. Komoto, P. van der Vleuten, and D. Faiman, Ed: Energy from the desert—Practical proposals for Very Large Photovoltaic Systems, EarthScan (2007-1)

(32) "Euro-Supergrid with a EU-MENA-Connection", www.trec-eumena.net

黒 川 浩 助 （正員） 1965 年 3 月早稲田大学第一理工学部電

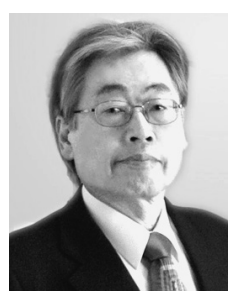
気工学科卒業。同年 4 月通商産業省工業技術院電 気試験所入所後, 高電圧直流送電の研究に従事。 1974 年よりサンシャイン計画などで太陽エネル ギー・太陽光発電の研究。1996 年 5 月東京農工大 学教授に転任。2008 年 4 月より東京工業大学統 合研究院特任教授および東京農工大学特任教授。 早稲田大学工学博士。再生可能エネルギー協議会 代表, 国際太陽エネルギー学会理事。IEEE 会員。 